\title{
James K. Baxter and John Ball: a note on the source of 'Letter to Piers Plowman'
}

\author{
Peter Whiteford
}

First published by Pegasus Press in 1952, 'Letter to Piers Plowman' is one of the lesser-known poems of James K. Baxter (Collected Poems 125); a brief account of the circumstances behind its publication can be found in Frank McKay's Life (131). Among the few notices that the poem has received is an entry in The Cambridge Companion to Piers Plowman. Lawrence Warner's chapter there on the later medieval and early modern traditions of Piers Plowman extends its coverage to the twentieth century and includes a reference to Baxter's poem. The social and political context of 'Letter to Piers Plowman' is rather more immediate and specific than Warner realised, ${ }^{1}$ but one aspect of his note is worth further consideration. Warner writes (211):

So far as I am aware, this addition to the "Piers Plowman tradition"
is unique in alluding exclusively to the Piers of Ball's letter and
ignoring Langland and Piers Plowman: the rebel leader "Woke John
Trueman, John Nameless, and you at your furrow." But the spiritual
authority accorded Piers in this "Letter" is more that found in the
later visions of Langland's poem, and in the traditions we have been
surveying, than that in Ball's letters alone.

The primary audience for The Cambridge Companion would no doubt have been familiar with the reference to 'Ball's letter', but it is not well known beyond medieval historians and literary scholars, and its appearance in the context of James K. Baxter's work is of considerable interest, and even (as Warner implies) of some surprise.

John Ball himself is well known as one of the leading figures (with Wat Tyler) involved in the Peasants' Revolt of 1381. Ball, who was a priest, supported the peasants in their opposition to the poll tax and in their desire to be freed of the burden of working two days a week for free for the local church. He appears to have defied authority, both ecclesiastical and civil, on numerous occasions; in prison at the time the revolt began, he was 
freed by the rebels and preached a famous open-air sermon, but after the rebels dispersed he was arrested again, tried, and subsequently hanged, drawn and quartered in July, 1381, in front of the boy king, Richard II. Parts of Ball's sermon have been preserved (recorded in Walsingham's Historia Anglicana), as have copies of two letters he is credited with having written. ${ }^{2}$ It is one of these letters to which Lawrence Warner refers.

While William Langland's well-known poem was published frequently in the nineteenth and twentieth centuries, and might have been encountered easily enough by any reader of English literature in the 1950s when Baxter wrote his poem (especially one who read as voraciously as Baxter did), John Ball's letter was much less commonly published. Baxter is most likely to have come into contact with it during his time at university, and examination of the prescribed reading lists of the three colleges he attended (Otago, Canterbury and Victoria) covering the years 1944-1951 enables us to identify the probable source. 3

Although the three colleges have some noteworthy differences in the texts they prescribe, they are all comparable in the basic approach they take to constructing a curriculum for the study of English literature: that curriculum includes some study of the English language and its origins; it is predominantly focussed on canonical authors and historical periods; and it rarely ventures beyond British authors. Canterbury University College showed a particular interest in the work of Denys Thompson, F. R. Leavis and I. A. Richards in the late 1940s, 4 and Victoria University College was readier than others to include New Zealand authors, 5 but all three select the same texts to cover the Old English and Middle English periods: Wyatt's Anglo-Saxon Reader and Sisam's Fourteenth Century Verse and Prose. It is the latter, prescribed by all three for both the second and third years of the degree, that is significant here.

Originally published in 1921 and frequently reprinted (it was still common on New Zealand university reading lists until the end of the twentieth century, and in some cases into the twenty-first), the work is a collection of representative texts from the fourteenth century excluding Chaucer (an omission that Sisam likens to creating 'a body without a head' (p. $\mathrm{xxx})$ ). Including extracts from the other major authors of the period (Gower, Langland, the Gawain-poet) together with lesser-known authors such as Robert Mannyng, Richard Rolle, and John Wyclif and a variety of anonymous pieces, its intention was to illustrate 'the variety of interest that is to be found in the writings of lesser men' (p. xxx). University 
reading lists from those years typically included separate texts of Chaucer, no doubt in order to re-unite head and body.

Sisam's anonymous pieces include two sections of short popular items: a section he entitles 'Miscellaneous Pieces in Verse' (162-70) and another headed 'Political Pieces' (151-61). It is in the latter that we find 'John Ball's Letter to the Peasants of Essex'.6 Its appearance on the reading lists of the three colleges that we know Baxter to have attended makes it very likely that it is through Sisam's anthology that he encountered the letter of the revolutionary priest.

The text is short enough to be reproduced here in its entirety; in doing so, I preserve the spelling and orthography of Sisam's edition in order to give a sense of what Baxter would have read (160-61).7

IOHON SCHEP, som tyme Seynte Marie prest of 3ork, and now of Colchestre, gretep wel Iohan Nameles, and Iohan pe Mullere, and Iohon Cartere, and biddep hem pat pei bee war of gyle in borugh, and stondep togidre in Godes name, and biddep Peres Plouzman go to his werk, and chastise wel Hobbe be Robbere, and takep wip zow Iohan Trewman, and alle hiis felawes, and no mo, and loke schappe zou to on heued, and no mo.

Iohan be Mullere hap ygrounde smal, smal, smal;

pe Kynges sone of heuene schal paye for al.

Be war or ye be wo;

Knoweb zour freend fro zour foo;

Haueth ynow, and seith 'Hoo';

And do wel and bettre, and fleth synne,

And sekep pees, and hold zou perinne;

and so biddep Iohan Trewman and alle his felawes.

The fictional names included in the letter-John Trueman, John Nameless and Hob the Robber-must have caught Baxter's attention enough that he recalled them when he came to write his own poem, and it is possible that his exposure to this little known political piece may be the reason that Baxter adopted the letter form for his own work. Apart from these allusions, however, it is difficult to see any real influence of Ball's letter.

The second sentence quoted at the outset from Warner also deserves some further consideration. Quite rightly, I believe, he reaches the same conclusion that Baxter is not significantly influenced by Ball's letter, suggesting instead that it is 'the later visions of Langland's poem' that we should look to to account for the figure of Piers Plowman that emerges in Baxter's poem. I am not persuaded, however, that Baxter shows any awareness of the later visions. 
It is notoriously difficult to give any summary of The Vision of Piers Plowman-a poem that has been described as the greatest English poem of the Middle Ages, but at the same time as being the least artistic poem of the fourteenth century. Sometimes such conflicting views are expressed by the same critic: C. S. Lewis, for example, suggests that Langland achieves a sublimity that far exceeds anything found in Chaucer and rivals that of Dante, but goes on to say that 'he is confused and monotonous, and hardly makes his poetry into a poem'. 8

The poem is extant in over fifty manuscripts, none of them authorial; it exists in several different versions or revisions; it occupied its author for most of his adult life; and it remained unfinished at his death. Generically, it combines estates satire with personification allegory and dream vision, and among its many unusual features is that the central figure, the narrator Will, is asleep through most of its seven thousand lines. His dream experiences or visions form the core of the poem.

Perhaps the best known and most frequently anthologised parts of the poem include: the opening vision of a dysfunctional human society (the field of folk); the confessions of the seven deadly sins; Piers Plowman's apparently inexplicable action in tearing the pardon sent from God (Saint Truth); and the central climactic vision of Christ's Crucifixion and the harrowing of hell. Sisam ignores all of these. The first of two extracts that he includes covers the first appearance of Piers within the poem, but it ends before the tearing of the pardon; the second is a passage found only in the later revison of the work in which Will (momentarily awake) provides a brief account of his own life. While they are both perfectly representative of Langland's work, neither passage, it must be said, displays the enormous power of his writing and the force of his allegorical technique. Nor do they count as later visions.

The first of the two sections that Baxter might have read begins with the titular figure of Piers Plowman offering to guide people on a pilgrimage to Truth, if they will first help him to plough his half acre. The passage begins with a sense of optimism and a shared commitment to communal work, but that communal spirit is quickly lost and by midday many have ceased work. They feign illness and disability in order to avoid manual labour, but still seek to be supported by the community. The reaction of Piers is one of anger and righteous indignation, and he summons the figure of Hunger to inflict pain on those he considers wastrels. Baxter may have taken some images from this section: the ideal of a mutually supportive community 
would certainly have appealed to him, although its hierarchical structure and endorsement of authority would hardly have done so. Equally, the image of Famine ploughing a furrow may be drawn from this selection, but if so Baxter has reversed the use of the image. For him, the figure of Famine is a wholly negative one, whereas Langland-or Piers-quite deliberately (and in the short term successfully) calls upon Hunger to force people to work.

The second of Sisam's selections is found only in the final revision of the poem (the so-called C-text), a quasi-autobiographical passage in which the narrator names himself as Will, reveals that he is a cleric in minor orders, that he lives in London with his wife and daughter and, being unfit for manual labour because of his height, earns his living by praying for the souls of others. The degree to which this passage may be trusted as autobiography is much disputed, but there is certainly nothing in it that corresponds to the content of 'Letter to Piers Plowman'.

That Baxter made use of Sisam's anthology seems beyond doubt. It had been a requirement of his university study, whichever college he attended, and his allusion to the little known text of John Ball is most readily explained by its presence in Sisam's work. On the other hand, his poem seems only in the most general way to have drawn on The Vision of Piers Plowman, and to the extent that it does draw on Langland for inspiration, it does not do so through any prompting from Kenneth Sisam's selections. However attentively he may have read his university texts for the purposes of examinations, this one at least had little direct impact on his verse.

\section{WORKS CITED}

Astell, Ann W. Political Allegory in Late Medieval England. Ithaca and London: Cornell University Press, 1999.

Baxter, James K. Collected Poems. Ed. J. E. Weir. Auckland: Oxford University Press, 1988.

Dean, James M. (ed.). Medieval English Political Writings. Kalamazoo, Michigan: Medieval Institute Publications, 1996. Also available online at $<$ http://d.lib.rochester.edu/teams/publication/dean-medieval-englishpolitical-writings $>$ [13 Dec. 2016]

Langland, William. The Vision of Piers Plowman. Ed. A. V. C. Schmidt. London: J. M. Dent, 1995 . 
Legouis, Emile. A Short History of English Literature. Oxford: Clarendon Press, 1950.

Lewis, C. S. The Allegory of Love. Oxford: Oxford University Press, 1936.

McKay, Frank. The Life of James K. Baxter. Auckland: Oxford University Press, 1990.

Middleton, Anne. 'William Langland's "Kynde name": Authorial Signature and Social Identity in Late Fourteenth-Century England' in Literary Practice and Social Change in Britain, 1380-1540. Ed. Lee Patterson. Berkeley: University of California Press, 1989, 15-82.

Sisam, Kenneth. Fourteenth Century Verse and Prose. Oxford: Oxford University Press, 1921 (corrected edn. 1937).

Walsingham, Thomas. Thomae Walsingham, quondam monachi S. Albani, Historia Anglicana. Ed. H. T. Riley. Rolls Series 28. 2 vols. London: Longman, Green, 1863-64. [Ball's Letter is found in II, 33-34.]

Warner, Lawrence. 'Plowman traditions in late medieval and early modern writing' in The Cambridge Companion to Piers Plowman. Ed. Andrew Cole and Andrew Galloway. Cambridge: Cambridge University Press, 2014.

\section{NOTES}

1 For an identification of the immediate context, see my essay on Baxter's social voice in the volume on Baxter's Collected Prose (ed. Geoff Miles and Peter Whiteford, forthcoming).

2 For a fuller account of John Ball's life, the political context of his work, and an edition of the sermon and letters, see Dean. There are suggestions that Ball may have written up to six letters. For further discussion, see the second chapter of Astell, “Full of Enigmas”: John Ball's Letters and Piers Plowman', especially 44-45.

3 I am very grateful to my research assistant, Dr. Hannah Parry, for collating the lists of prescribed materials from the university calendars.

4 Canterbury University College named three of Thompson's works: Reading and Discrimination, Between the Lines and Voice of Civilisation together with Culture and Environment by Leavis and Thompson.

5 The Victoria University College lists included Mansfield, Mulgan and Curnow, together with scholarly works by Professor Ian Gordon.

${ }^{6}$ The title is a translation: in the manuscript in which the letter is preserved (British Library Royal MS 13. E. ix, f. 287r) it is entitled 'Littera Johannis Balle missa communibus Essexiae'.

7 The names are either a subterfuge intended to mask the identity of the people involved, or are intended to refer to generic occupations. John Ball's reference to himself here as 'Schep' (i.e shepherd) may be a gesture to his role as spiritual pastor, but also recalls the opening lines of Piers Plowman in which Will clothes himself 'in 
shroudes as I a shepe were'. On the practice of such 'signing' and its possible application to John Ball's letter, see Anne Middleton. The text is glossed and annotated in Dean.

8 The first comment is to be found in A. V. C. Schmidt's Introduction to his edition of Piers Plowman; the second in Legouis, 36. C. S. Lewis's remark is in The Allegory of Love, 159-61. 